\title{
Effectiveness of Government Regulation Concerning Ownership of Residential Housing in Badung District
}

\author{
I Wayan Rasmawan,SH.,MH. \\ Law Doctoral Program Student, Faculty of Law, Udayana University, Bali - Indonesia
}

\begin{abstract}
This study entitled The Effectiveness of Government Regulations Regarding Foreign Residential Housing Ownership in Badung Regency. The reason for choosing this title is to empirically examine the implementation of Government Regulation Number 103 of 2015 concerning Housing Ownership / Residential by foreigners, especially in Badung Regency. Starting from the title of the research, the problem can be formulated as follows: (1) Do foreigners who have a house / residence in Badung Regency obey and follow the provisions stipulated in the Government Regulation. Number. 103 of 2015? (2) What factors affect the effectiveness of the implementation of Government Regulation No. 103/2015, especially in BadungRegency. The results of the study stated that the majority of government officials, the public, especially landowners and foreigners, were not aware of Government Regulation Number 103 of 2015 concerning the ownership of residential houses by foreigners on use rights land. Therefore, it can be concluded that the Government Regulation is not effective, especially in Badung Regency because foreigners prefer to choose lease rights or ownership rights by way of addressing Indonesians (Nominees) and then build houses / dwellings with consideration of cheaper land rent prices, the process is simple and the timeframe adjusted to the wishes of foreigners themselves to the landowners.
\end{abstract}

Keywords: Effectiveness, Foreigners, Nominees

DOI: $10.7176 / \mathrm{JLPG} / 94-03$

Publication date: February $29^{\text {th }} 2020$

\section{Introduction}

The rapid development in all fields has consequences for the increased supply of land. Facing these conditions the government needs to dynamically and creatively respond to complex conditions in order to realize social welfare for all Indonesians.

The development of the tourism sector, especially in the area of Bali is very fast, the local government should anticipate by preparing supporting facilities for tourism needs. One of the most important is the availability of accommodation, especially lodging for foreign and domestic tourists. Remembering that Bali relies on tourism as a locomotive of economic development that can benefit the community through the creation employment and at the same time as one of the dynamics of changes in social life, economics including cultural aspects.

Foreigners who come to Bali today are not only tourists, there are also workers or business activities both in the field of trade and services. For foreigners who carry out business activities for a relatively longer period of stay, therefore they are not always staying overnight at the hotel. Most foreigners will rent or buy land to build houses or residences. More and more foreigners who are interested in owning a house or dwelling in Indonesia, including in Bali, of course, it is necessary to regulate the type of land rights that can be owned by foreigners or foreign legal entities to ensure investment security and legal certainty of ownership of residential or residential property.

In Government Regulation number 103 of 2015 it is stated that what is meant by foreigners domiciled in Indonesia, hereinafter referred to as foreigners, is a person who is not an Indonesian citizen whose existence provides benefits, does business, works or invests in Indonesia. The houses or dwellings that can be owned by foreigners referred to are:a. Single House is a house that has its own plot and one of the walls of the building is not built right on the plot which is built on the Right to Use land or Right to Use on land that is controlled based on the agreement to give the Right to Use on Land of Ownership with the Act of Land Deed Making Officer (PPAT ). b. Sarusun (unit of flats) is a unit of flats whose main purpose is to be used separately with the function as a place of residence and has a means of connecting to the main road built on a piece of land for Use Rights.

The term of the Right to Use is granted for 30 years can be extended for another 20 years. In the event that the extension as intended ends the Right to Use can be renewed for a period of 30 years. Observing the above reality the writer is interested in researching related to the problems mentioned above.

thus from the above background the problems can be raised as follows: (1) What are foreigners who have residential / residential houses in Badung Regency obey and follow the provisions stipulated in the Government Regulation Number. 103 of 2015? (2). What factors influence the effectiveness of the implementation of Government Regulation Number 103 of 2015 especially in Badung Regency? 


\section{Research Methods}

In this research using empirical research that is field research to obtain primary data. ${ }^{1}$ The location of the study was conducted in Badung Regency related to the ownership of residential houses / dwellings owned by foreigners, by conducting interviews in government / non-government institutions / institutions including the National Land Agency Office, Immigration Office, Trade Office, Licensing Office, Unit Office Civil Service Police and Notary Office, and some foreigners and people who own land that is leased or bought by foreigners.

\section{Results and Discussion}

\subsection{Ownership of residential houses / dwellings by foreigners in Badung Regency.}

Based on research conducted in Badung Regency with foreign respondents each of 10 (ten) people for each subdistrict in Badung Regency namely Kuta District, Kuta Selatan District and Kuta Utara District, findings were found that foreign ownership of houses by foreigners very little is found on land use rights. To obtain the right to use can be done by buying land and buildings whose land status is the right of use or buying a house on private property, then foreigners apply for use rights after fulfilling all the specified conditions. What is found is that foreigners buy land with the name of the person Indonesia (nominee) then builds a house / dwelling on the property rights. The ownership of the house / dwelling on the lease rights by leasing with the landowner is usually made before a notary with an authentic deed in accordance with the lease period and agreed terms. by landowners and foreigners, then build a house / dwelling. Ownership of land ownership rights by foreigners with ownership in disguise, this way is clearly a deviation and violation in accordance with Article 23 paragraph 2 of the BAL and Government Regulation.Number.103 years. 2015. Land ownership in a veiled way is done by using the Strooman system (the guise system). The practice that is often carried out relates to the model of land ownership using this guise is to conduct the sale and purchase of private property by Indonesians where the source of money for payment of land comes from foreigners. In fact this kind of act can be categorized as legal smuggling.

Issues relating to ownership of houses / dwellings by foreigners can be analyzed from the perspective of the legal system theory of L. Friendman, ${ }^{2}$ especially legal culture or legal culture, namely attitudes and values concerning the understanding of foreigners of regulations relating to land rights. From the point of view of foreigners that the rules regarding ownership of residential houses and dwellings by foreigners on land use rights do not get a logical place in the cultural framework of society (read foreigners), because in practice foreigners are more inclined to see economic interests in terms of interests the profit and loss rather than the juridical interest in choosing a house / dwelling especially in Badung regency. Besides that, the house price above the right to use is quite high, namely for a single house, the minimum price of a house that can be purchased with a minimum price of Rp. 3,000,000,000.00 (three billion rupiah) and to get a residential in the form of a flat / apartment at a minimum price of Rp. 2,000,000,000.00 (two billion rupiah) in accordance with the price provisions as set out in the attachment to the Regulation of the Minister of Agrarian Affairs and Spatial Planning / Head of the National Land Agency of the Republic of Indonesia Number 13 of 2016 concerning Procedures for Granting, Releasing or Transferring the Right to Ownership of Housing Rights Or Occupancy By Foreigners Who Are Domiciled.

The choice of house / dwelling by foreigners also involves legal awareness, in this case foreigners have no legal awareness in themselves obeying the provisions that have been regulated in Government Regulations. Number 103 Year 2015. According to SoerjonoSoekanto legal awareness is part of the legal culture which is awareness about human values about existing laws or expected laws. Abdurrahman emphasized that the legal culture is the overall attitude of the community members and the existing system of values in society that will determine how the law should apply in the society concerned. In this context concerns the attitude of foreigners choosing land rights based on their own interests rather than based on legal interests. The choice of land rights by foreigners is also caused by the methods contained in Government Regulation No. 103/2015 not in accordance with living values in society. This is in line with Daniel S. Lev's view of the legal culture especially the substantive legal culture which consists of basic assumptions regarding the distribution and use of resources in society, right and wrong from a social perspective and so on because the assumptions change. On the other hand, legal awareness according to SutandyoWidnyosoebroto is the willingness to obey the law is a determinant of the enactment of the law. Acontrario can be said that without the willingness of foreigners to obey the law, the law will not apply.

Referring to the results of research and legal theory as well as the opinions of legal experts when related to the choice of foreigners towards the house / dwelling as regulated in Government Regulation No. 103/2015, it was found that more foreigners disobeyed the provisions of the regulation, evidently more foreigners choose the right of lease and ownership rights to establish a residential house or dwelling rather than choosing a house / dwelling on land of use rights as required in Government Regulation No. 103/2015, especially in Badung Regency. This is more influenced by legal culture and legal awareness of the community (read by foreigners).

\footnotetext{
${ }^{1}$ SoerjonoSoekantodan Sri Mamudji,, 1985 Normative Legal Research, a brief review, , PT. Raja GrafindoPersada, Jakarta

${ }^{2}$ Friedman, Laurent M., 1996, The Legal System : A Social Science perspective, Rusell Sage Foundation, hal 16.
} 


\subsection{Factors Affecting the Effectiveness of Regulations Regarding Foreign Ownership of Residential / Occupied Homes Especially in Badung Regency.}

After conducting research in 3 (three) Subdistricts in Badung Regency, namely KutaSubdistrict, South KutaSubdistrict and KutaUtraraSubdistrict, some foreigners who were made respondents, found several factors that influence the effectiveness of the implementation of Government Regulation No. 103/2015 including:

a. The substance contained in Government Regulation Number 103 of 2005; b. The structure constitutes an Executor, namely Government and non-Government institutions which are given the authority to implement Government Regulation Number 103 of 2015 and its supporting facilities; c. The culture of the people, especially foreigners who are the subject of the regulation.

The substance of the law (legal substance) is the method or norm contained in the Government Regulation, namely the subject is a foreigner and the object is a residential building or dwelling, whether single or flats and how to obtain land rights allowed for foreigners. The legal structure includes various institutions that support the operation of the legal system or implementing institutions including the National Land Agency, Badung Regency Regional Government, Immigration Office, Trade Office, Notary Office. Legal culture (legal culture) in this case concerns the culture of strangers who are individualistic and materialistic oriented to personal interests and benefits.

The substance of Government Regulation Number 103 of 2015 is basically that the subject of the regulation is foreigners and the object is a residential house on the land of use rights. Difficulties of foreigners obtaining usage rights because of the requirements required to have a work permit or residence permit as stipulated in the provisions of the Government Regulation. Padalah most foreigners visiting Bali, especially to Badung Regency as tourists and also interested in having a house or residence. For foreigners who qualify for the right to use, feel that the right to use is a long process of administration and incur significant costs and the period of usage rights is also considered not too long and does not guarantee legal certainty for the period of ownership due to the extension and renewal of rights. Foreigners are worried that for the extension and renewal of their usufructu no longer qualify as holders of usufructuary rights.

The purpose of the government is to issue Regulations on the ownership of residential houses and dwellings by foreigners in fact to guarantee legal certainty and certainty of the rights of foreigners in obtaining land rights for houses / dwellings. obtaining land rights for residential houses of foreigners using the method in accordance with their own will to obtain land rights. From the perspective of Roscoe Pound's theory, the aim of the government is to issue Government Regulation No. 105/2015, as a rule instrument for engineering society (law is a tool of social engineering). According to Lily Rasidi, ${ }^{1}$ this theory is a legal approach to the community, that is, the law becomes an instrument to direct the community towards the desired goal, that if necessary eliminate the habits of society which are considered negative. Whereas Mochtar Kusumaatmadja said that law is a means of community renewal based on the assumption that there is order or order in the development and renewal efforts that are desirable or even considered absolute.

The findings obtained from research in several offices / government agencies in the Badung Regency mentioned above that in the management of documents as a requirement for obtaining land use rights and Building Permit (IMB) residential houses / dwellings by foreigners have not fully implemented online service standards and still some are carried out manually so that the speed of service is not as expected by foreigners. The document processing service as a support and application for the right to use itself up to now has not provided a fast and accurate service. As a result, most foreigners feel disappointed with the length of the settlement process to obtain the Right to Use.

\section{Conclusions}

1. To obtain a house / dwelling place for foreigners, they prefer to choose lease rights and ownership rights in the name of local people (nominee) and no one chooses use rights, with the following considerations: The lease rights are simple. Notary office or made under the hand between the land owner and a foreigner and to obtain the right to rent the costs incurred is smaller than the right of Use.The property rights have a high value of enomonis and there is no term of the rights, so there is no need for extension of the land rights as the use rights.

2. Effectiveness of the implementation of Government Regulation Number 103 Year 2015 concerning Ownership of Residential Houses or Occupancy with Foreigners domiciled in Indonesia, especially in Badung Regency does not apply effectively. This is caused by various factors including: (1) Substance of Government Regulation No. 103/2015, specifically regarding the requirements for foreigners to have usage rights (2) Facilities and supporting facilities, especially concerning the process of making documents for requests for use rights and applications for use rights itself has not been fully carried out online so the usage rights application process cannot be served quickly according to the hopes and needs of foreigners. (3) The legal culture of the community in this case the landowners in Badung Regency have a belief that the inherited land has a religious magical value so it tends to lease their land rather than sell it to foreigners. From a cultural perspective foreigners who

${ }^{1}$ Rasjidi, Lili, 1993, Filsasfat hukum apakah hukum itu, Bandung : PT. Remaja Rosalakarya, hal. 49 
tend to be individualistic and materialistic view that everything that is done is oriented towards personal interests and benefits without regard to aspects of legality.

\section{REFERENCES}

Brugging, J.J.H, 1999, Refleksi Tentang Hukum (alihbahasa Arief Sidharta), Citra Aditya Bakti.

Friedman, Laurent M., 1996, The Legal System : A Social Science perspective, Rusell Sage Foundation.

Moleong, lexy. J, 1990, Metodologi Penelitian Kualitatif, Bandung : PT. Remaja Rosdakarya.

Pitana I Gde, 1992, Daya Dukung Bali Terhadap Kepariwisataan dalam asfek Sosial Budaya. Dalam I G N Bagus dkk (eds), Pembangunan Bali Berwawasan Budaya Terbitan Khusus Majalah Ilmiah UnudTh.I, No. 1.

Pound, Roscou, 1954, An Introduction to the Philosophy of law, New Haven Yale University Pres.

Raharjo Satjipto, 1979, Hukum dan Perubahan Sosial, Bandung : Alumni.

Rasjidi, Lili, 1993, Filsasfat hukum apakahhukum itu, Bandung : PT. Remaja Rosalakarya.

Soekanto, Soerjono, 1983, Penegakan Hukum, Cetakan Pertama, Bandung :Binacipta.

Suparjo, Sujadi, 1997/1998, Analisis kebijakan pertanahan menghadapi era globalisasi Ekonomi,Jakarta :Lembaga Penelitian Universitas Indonesia. 